\title{
THE POWER AND PROMISE OF 21ST- CENTURY LITERARY CRITICISM
}

\author{
Leonor M. Martínez Serrano, Universidad de Córdoba ${ }^{1}$ \\ Email: lemase09@gmail.com
}

\begin{abstract}
Literature is an ancestral enterprise whereby humans seek to understand reality and make sense of the world at large. A sophisticated construct of the human imagination, Literary Criticism has served the purpose of scrutinizing verbal works of art from a wide range of critical perspectives to find out the truths contained in them about humanity and our world. This is a way of honouring the deep thinking and the beauty inherent in Literature. In this paper, we look at the concept of 'liminality' in Anglophone Studies, as well as to the power and promise of 21st-century Literary Criticism as part of the Humanities, at a time where there is a fierce need for a transdisciplinary approach to the study of literature that brings together the lessons of contemporary Philosophy and other relevant fields of knowledge that may shed light on our understanding of literature. Key words: Literary Criticism, poetry, Humanities, liminality, Philosophy, Northrop Frye, Robert Bringhurst.
\end{abstract}

Título en español: "El poder y la promesa de la Crítica literaria del siglo XXI"

Resumen: La literatura es una empresa ancestral con la que los seres humanos tratan de comprender la realidad y el mundo en toda su extensión. Sofisticado constructo de la imaginación humana en sí misma, la Crítica Literaria ha estudiado las obras literarias desde múltiples perspectivas teóricas a lo largo de los siglos con el objeto de sacar a la luz las verdades que encierran sobre la humanidad y nuestro mundo. La Crítica Literaria no deja de ser una forma de honrar el pensamiento profundo y la belleza inherentes a la propia literatura. En este artículo meditamos acerca del concepto de 'liminalidad' en los Estudios Anglófonos, y reflexionamos sobre el poder y la promesa de la Crítica Literaria del siglo XXI como parte de las Humanidades, en unos tiempos en que urge apostar por un acercamiento holístico y transdisciplinar al estudio del fenómeno literario que aúne las lecciones de la Filosofía contemporánea y de otras disciplinas que acaso puedan arrojar luz sobre nuestra comprensión de la literatura

Palabras clave: Crítica literaria, poesía, Humanidades, liminalidad, Filosofía, Northrop Frye, Robert Bringhurst.

\section{WORDS IN TIME: THE INEXHAUSTIBLE BEAUTY OF LITERATURE}

Since the very cradle of humanity, Literature has been sanctioned as a prestigious widespread cultural practice whereby human beings make sense of their world. It is by

Date of reception: 1 August 2015

Date of acceptance: 30 November 2015 
means of the most privileged use of language that we may come to understand reality, the universe and our place within it. Not without reason, Canadian critic Northrop Frye claims in an enlightening essay entitled "Verticals of Adam" that literature is a construct of the human imagination and that "the constructs of the imagination tell us things about human life that we don't get in any other way." (1964: 125) Everything that happens in space and in time vanishes into nothingness; it is only the imagination that can unveil the hidden pattern beneath the unstoppable flux of reality, for "a great work of literature is also a place in which the whole cultural history of the nation that produced it comes into focus." (1964: 123) In another probing meditation entitled "Giants in Time", Frye contends that the true limit of the imagination is "a universe entirely possessed and occupied by human life." (1964: 80) This is a statement full of powerful resonances to which we shall return in due time. At any rate, language is the most complex art object, a true forest of symbols, an endless work in progress, and the treasure-house of all the knowledge that has been conquered by men and women over time. There is no end to language, as there is no end to human knowledge, or to the capacity of the world to surprise us. There is no end either to human creativity or to our unquenchable desire to understand the universe and the ineffable mystery of what is. As Frye puts it in "The Keys to Dreamland", "we can't speak or think or comprehend even our own experience except within the limits of our own power over words, and those limits have been established for us by our great writers." (1964: 102) Earlier, Ortega y Gasset, ${ }^{2}$ Ludwig Wittgenstein and Martin Heidegger had claimed something similar: die Sprache spricht, ${ }^{3}$ language speaks through us, and "Die Grenzen meiner Sprache bedeuten die Grenzen meiner Welt", which is to say that the limits of our language are the limits of our world.

Literary Criticism serves the purpose of scrutinizing verbal works of art from a wide range of critical perspectives - from the Structuralist and New Criticism tenets that prevailed in roughly the first half of the 20th century, through Psychoanalytic interpretation and Reception Theory, to Poststructuralism, Postmodernism, Feminism, Ecocriticism and Postcolonialism. Literary Criticism is an art object, and also an art form which is not devoid of creativity. It is the expression of the exuberance of human language; it is one more feat of the human imagination. The role of Literary Criticism lies in unveiling the hidden universal patterns beneath literature that are recurrent constellations formed by timeless and non-spatial ideas, feelings and emotions. Literature is the sublime embodiment of the

2 In his landmark essay "Miseria y esplendor de la traducción", the Spanish philosopher Ortega y Gasset writes: "Las lenguas nos separan e incomunican, no porque sean, en cuanto lenguas, distintas, sino porque proceden de cuadros mentales diferentes, de sistemas intelectuales dispares - en última instancia -, de filosofías divergentes. No sólo hablamos en una lengua determinada, sino que pensamos deslizándonos intelectualmente por carriles preestablecidos a los cuales nos adscribe nuestro destino verbal." (1964: 446). A few centuries earlier, Wilhelm von Humboldt had drawn the crucial dichotomy between language as ergon and language as energeia: "Die Sprache in ihrem Wesen aufgefaßt, ist etwas beständig und in jedem Augenblick vorübergehendes... Sie selbst ist kein Werk (Ergon), sondern eine Tätigkeit (Energeia)." (1978: 418)

3 In Unterwegs zur Sprache, Martin Heidegger claims: “... das Sein istet, die Welt weltet, die Zeit zeitigt, das Nicht nichtet, das Ding dingt, das Ereignis ereignet, die Sprache spricht." (1985: 30) And also: "Der Mensch spricht nur, indem er der Sprache entspricht. Die Sprache spricht. Ihr Sprechen spricht für uns im Gesprochenen. [...] Die Sprache ist das Haus des Seins." (1985: 156) Later on, in Identität und Differenz, Heidegger observes once again: "Im Ereignis schwingt das Wesen dessen, was als Sprache spricht, die einmal das Haus des Seins gennant wurde." (1988: 92) 
best that has been imagined and thought by humans over time. Hence, Literary Criticism is essentially concerned with an archaeology of the human imagination, and as such it is part of a huge body of disciplines made out of words that systematically pursue an archaeology of human knowledge. To reflect on literature implies an archaeological vigilance, a persistent form of thinking whose path is to expose, examine and elaborate that which still remains obscure, unthematized, even unsaid, in an author's thought or oeuvre. And to be archaeologically vigilant in the practice of Literary Criticism means to dispel obscurities and to draw humans' attention to that which remains the same in spite of the passage of time.

However, la raison d'être of Literary Criticism is inextricably linked to the primordial statements on truth pronounced by Literature from time to time. T. S. Eliot, Ezra Pound, Northrop Frye, Harold Bloom, Hugh Kenner and Helen Vendler (some of the pre-eminent critical minds of the 20th century) knew deep inside what it means to pursue Literary Criticism with intellectual integrity, honesty and rigour. Like Literature itself, Literary Criticism is not devoid of creativity either: the gesture of scrutinizing literary works of art to find out the truths contained in them about humanity and our world is also a way of honouring the deep thinking and the beauty inherent in Literature. Like Philosophy, committed Literary Criticism is in pursuit of truth - and also of beauty, if permitted. In this sense, it is necessary to qualify the term 'truth' following the intuitions of contemporary Philosophy. In his groundbreaking Manifesto for Philosophy, French philosopher Alain Badiou claims that there are four types of generic procedures or conditions of Philosophy - the matheme, the poem, political invention and love - , which may produce different kinds of truth: scientific, artistic, political and amorous truths. According to Badiou, a truth is a paradoxical thing, as it is "at once something new, hence something rare and exceptional, yet, touching the very being of that of which it is a truth, it is also the most stable, the closest, ontologically speaking, to the initial state of things." (1999: 36) Different paths may lead to and produce diverse forms of truth, which suggests that knowledge is something in the making, rather than a thing already made. In this respect, it is a matter of the utmost urgency to restore such concepts as truth, beauty and good to the very centre of the study of the Humanities. It is by no means an easy task, though.

In the early decades of the 21 st century - a Zeitgeist marked by a fiery relativism and a widespread nihilism that highlights the impossibility of gaining access to ultimate truths - , the state of Literary Criticism and the sheer bulk of critical work being written on primary texts (i.e., literary works of art) should prompt us to rethink what is central and what is peripheral in the field of literary research when it comes to Anglophone Studies. It is our contention that, in the context of the so-called Knowledge Society, some of the best writing and the most profound thinking about Literature, Culture or Language might well be taking place outside academia. What is peripheral might be truly pertinent or relevant, and what is liminal might be just a luminous contribution to the ever-growing treasure-house of human knowledge. Liminality is a powerful conceptual tool that may help us understand how new forms of knowledge are being rehearsed right now. Liminal spaces are peripheral spaces in society where creativity, communal solidarity and ideas that have value may truly flourish and contribute something new to the ongoing conquest of knowledge at a global scale. Thus, independent small presses across the USA and Canada publishing limited-edition broadsides, books or chapbooks, free-lance researchers, brave translators and independent 
thinkers, self-made scholars writing from within the periphery or margins of Empire might be pronouncing temporary truths that are worthy of our attention. Among these independent scholars and lucid thinkers are such authors as Canadian poet-philosopher Robert Bringhurst, who has written an impressive body of work that embodies what could be called Lyric Criticism. Thus, apart from pursuing his career as a poet, typographer, cultural historian and translator of Classical Haida literature, Bringhurst has written book-length meditations and collections of probing essays on literature, philosophy, language, translation and ecology under the titles The Tree of Meaning (2006), Everywhere Being Is Dancing (2007) and What Is Reading For? (2011).

What appears to be crystal-clear is that we are witnessing a proliferation of critical writing (mostly in academic contexts and as opposed to primary or primordial writing) for which there is no precedent in History: in the age of multi-modal communication, a species of writing that is subsidiary to the primary literary work is thriving and being disseminated through a huge variety of channels (academic journals, printed and electronic publications). Needless to say, writing is a powerful form of technology that endows humans with a limitless capacity to preserve knowledge to the benefit of future generations. Like dignity and our capacity to love, knowledge is possibly the most precious thing we humans have; this is why it should not be turned into a commodity. Real knowledge belongs to humankind as a whole, to the human species. The construction of knowledge is a collective and cooperative enterprise, but how is lasting, valuable knowledge created and sanctioned as such, particularly in the field of the Humanities? And who owns human knowledge? Is it not a prerogative pertaining to the whole of humankind? Is it not true that, as Goethe said some hundred years ago, we humans know everything if we join efforts? The power and promise of Literary Criticism in the new millennium are part of the challenge, but also part of the answer to this crucial epistemological dilemma.

\section{THE KNOWLEDGE MOST WORTH HAVING}

First thing is facts. What is Literary Criticism? And what is it for? The simplest questions are not only the hardest to answer, but also the most important to ask. There is no simple answer to these simple questions, even though some of the most pre-eminent minds of all times have sought to answer them in a sensible manner, even with warmth and conviction. One of those pre-eminent minds is called Northrop Frye, who is probably the most important Canadian literary critic, one who has made a lasting contribution to the critical thinking about the ultimate nature, value and uses of both Literature and Literary Criticism. To tweak a well-known phrase by Ezra Pound, Literary Criticism is the dance of the intellect among poetical words, for poetry is the beating heart of literature. ${ }^{4}$ To put it in simpler terms, Literary Criticism is the systematic study of specific instances of literature, it is a

\footnotetext{
4 In "Verticals of Adam", Frye elaborates on this central idea: "If literature is to be properly taught, we have to start at its center, which is poetry, then work outward to literary prose, then outward from there to the applied languages of business and professions and ordinary life. Poetry is the most direct and simple means of expressing oneself in words: the most primitive nations have poetry, but only quite well developed civilizations can produce good prose. So don't think of poetry as a perverse and unnatural way of distorting ordinary prose statements: prose is a much less natural way of speaking than poetry is.” (Frye 1964: 121)
} 
form of paying attention to the art of words, and literature is, among other things, an art of communication. The critic, who has been traditionally conceptualized as being a judge of literature, ought to know something about literature, for his function is "to interpret every work of literature in the light of all the literature he knows, to keep constantly struggling to understand what literature as a whole is about." (Frye 1964: 105) Understanding the totality of literature appears to be the ultimate goal of intellectually ambitious Literary Criticism.

In his beautifully-written book entitled The Educated Imagination (1964), Northrop Frye contends that literature is the most valuable of studies because it educates the imagination, where we live every day of our lives, in all our private and public decisions. He is a true champion of the pedagogical value of literature, which he conceives of as being the most sophisticated tool to educate the minds of young people and adults alike. In this respect, literature is part of the very core of the Humanities. In the essay "Verticals of Adam", Frye offers an ambitious program on the teaching of literature at different educational levels and he establishes three contexts for the study of English: the context of languages other than English, the context of arts other than literature and "the relation of literature to other subjects, such as history, philosophy and the social sciences, that are built out of words." (1964: 117) He claims that "people who call themselves humanists, and who include students of literature, have always been primarily people who studied other languages. The basis of the cultural heritage of English speaking peoples is not in English; it's in Latin and Greek and Hebrew." (1964: 118) Hence the totality of the literary experience goes beyond the boundaries of single languages or historical periods and it embraces the great achievements of all human civilizations. And he explores in detail the true nature of the human imagination, which is the very basis of all human endeavour that is worth the effort:

Everything man does that's worth doing is some kind of construction, and the imagination is the constructive power of the mind set free to work on pure construction, construction for its own sake. The units don't have to be words; they can be numbers or tones or colors or bricks or pieces of marble. It is hardly possible to understand what the imagination is doing with words without seeing how it operates with some of these other units. (Frye 1964: 120)

Now we begin to understand Frye's point in claiming that the limit of the imagination is "a universe entirely possessed and occupied by human life." The world makes sense inasmuch as it is perceived and grasped by the human mind; it is the human presence that renders every corner on Earth truly meaningful. And what is more: art is the offspring of the confrontation of the human mind with the world outside and the world within. And so is science. Their common mother is curiosity. Frye then goes on to draw a relevant distinction between the sciences and the arts in his essay "The Motive for Metaphor":

Science begins with the world we have to live in, accepting its data and trying to explain its laws. From there, it moves toward the imagination: it becomes a mental construct, a model of a possible way of interpreting experience. The further it goes in this direction, the more it tends to speak the language of mathematics, which is really one of the languages of the imagination, along with literature and music. Art, on the other hand, begins with the world we construct, not with the world we see. It starts with the imagination, and then works toward ordinary experience: that is, it tries to make itself as convincing and recognizable as it can. You can see why we tend 
to think of the sciences as intellectual and the arts as emotional: one starts with the world as it is, the other with the world we want to have. (Frye 1964: 23-24)

In his illuminating book The Stubborn Structure. Essays on Criticism and Society, a collection of 16 essays published in 1970, Northrop Frye still dwells on the same themes: on what knowledge is most worth having, on what kind of morality is relevant to scholarship, on what the Humanities provide that is not provided by the Sciences, and on the values of literary study itself. The essay titled "The Instruments of Mental Production" remains a powerful statement on the nature and value of human knowledge. It is indeed central to the whole Frye volume, and so it is no surprise that it should come first in the collection. In the opening lines of the book and the essay, Frye affirms with astonishing conviction that "the knowledge of most worth, whatever it may be, is not something one has: it is something one is." (1970: 3) And also: "the knowledge of most worth, for a genuine student, is that body of knowledge to which he has already made an unconscious commitment." (1970: 3) Frye dwells on the nature of worthwhile knowledge: "The only knowledge that is worth while is the knowledge that leads to wisdom, for knowledge without wisdom is a body without life." (1970: 15) The crucial point Frye makes is that knowledge is not something we own; we are what we know. Knowing, not owning: this is what understanding reality is all about. ${ }^{5}$ This is an illuminating insight into the ultimate sense of knowledge and the universal human vocation for learning. The knowledge of greatest worth is that which we have possibly become in an unconscious manner, without our noticing it. From there Frye proceeds to draw a distinction between theoretical and practical knowledge in the framework of the traditional conception of education we have inherited from Plato:

Plato divides knowledge into two levels: an upper level of theoretical knowledge (theoretical in the sense of theoria, vision), which unites itself to permanent ideas or forms, and a lower level of practical knowledge, whose function is to embody these forms or ideas on the level of physical life. What I have referred to in my title as the instruments of mental production consist of the arts, and we may see the major arts in Plato's terms as forming a group of six. Three of them are the arts of mousike: music, mathematics, and poetry, and they make up the main body of what Plato means by philosophy, the identifying of the soul of man with the forms or ideas of the world. The other three are the imitative or embodying arts, the arts of the techne, painting, sculpture, and architecture, which, along with all their satellites and derivatives, unite the body of man with the physical world. (Frye 1970: 7-8)

5 In a powerful poem entitled "Gloria, Credo, Sanctus et Oreamnos Deorum”, Robert Bringhurst dwells on the nature of human knowledge. The poem opens with the words "Knowing, not owning", which in their linguistic concision remind us that we do not own what we know. Knowledge usually brings a sense of intellectual safety or control, but also a form of dominion over what is known by the human mind. Humans want to know and need to know, which is a universal compulsion indeed, in much the same way they want to lead an authentic life. The whole history of humankind is nothing but a titanic effort sustained over time aimed at reaching towards absolute knowledge of what is. Self-absorbed as we are, human beings tend to think that we are at the top of creation and take for granted that we do have a right to manage the Earth and everything in it as we please. But this poem is precisely a praise of what is objectively and stubbornly real, a moving celebration of the inexhaustible richness of what is. The real is always more complex and interesting than whatever we might think or feel about it: "Knowing, not owning. / Praise of what is, / not of what flatters us / into mere pleasure. // Earth speaking earth, / singing water and air, / audible everywhere / there is no one to listen.” (Bringhurst 2009: 159) 
What Frye calls the primary instruments of mental production are the creative arts and the bodies of knowledge they inform. "The contemporary reason for their importance is that the arts of words and numbers are not only arts in themselves but informing languages for other disciplines. Words inform the bodies of knowledge that we call the humanities, as well as most of the social sciences; mathematics informs the sciences, more particularly the physical sciences." (Frye 1970: 16) Following in Frye's step, French philosopher Alain Badiou dwells in his Manifeste pour la philosophie on the different conditions of philosophy, that is: on the different paths leading to knowledge. Art, science, politics and love are all valid ways of producing lasting knowledge. Innumerable relevant questions may be asked at this point: Is it possible to draw a comprehensive, all-embracing map of human knowledge? What is the structure of knowledge? Is there such a thing as a centre and a periphery? And why is liminality such a promising space where new forms of knowledge may be rehearsed in the new millennium? What appears to be out of the question is that knowledge is an ever-expanding constellation of man-thought and man-made ideas and that Literary Criticism is part of the knowledge most worth having. If there is no end to human knowledge, it is possibly because there is no way of grasping the ultimate essence of things for good. This is why cooperative effort and solidarity across geographical and spatial boundaries are required to keep on expanding the domains of human knowledge.

\section{THE HUMANITIES AND THE UNDERSTANDING OF REALITY}

In ancient Greece, about 24 centuries ago to be more precise, Aristotle claimed in the opening lines of Book I his Metaphysics that all men and women want to know and to understand. ${ }^{6}$ He pointed to a basic intellectual necessity that has continued unabated over thousands of years. About three centuries later, somewhere else, in Rome, Seneca affirmed in his treatise De vita beata that the true vocation of all human beings was the pursuit of happiness, ${ }^{7}$ which he defined as being a cupiditas naturalis (that is, a natural, inescapable desire). Thus, the true vocation of the human beings from all ages and geographies is to know and to be happy, which is to say to love the world and, by loving it, to understand it and to let themselves be changed by the world. A few centuries later, in 1333, during a

6 These are the opening lines of Aristotle's Metaphysics I.I, 980a 21-7: "All men by nature desire to know. An indication of this is the delight we take in our senses; for even apart from their usefulness they are loved for themselves; and above all others the sense of sight. For not only with a view to action, but even when we are not going to do anything, we prefer sight to almost everything else. The reason is that this, most of all the senses, makes us know and brings to light many differences between things." The original source of the translation is The Complete Works of Aristotle. The Revised Oxford Translation, but the quote is lifted from Jonathan Lear's Aristotle: The Desire to Understand (1988: 1).

7 Seneca's De vita beata opens like this: "Vivere, Gallio frater, omnes beate volunt, sed ad pervidendum quid sit quod beatam vitam efficiat caligant; adeoque non est facile consequi beatam vitam ut eo quisque ab ea longius recedat, quo ad illam concitatius fertur, si via lapsus est; quae ubi in contrarium ducit, ipsa velocitas maioris intervallic causa fit." (1932: 98) In the English rendering by the Loeb Classical Library, it sings like this: "To live happily, my brother Gallio, is the desire of all men, but their minds are blinded to a clear vision of just what it is that makes a happy life; and so far from its being easy to attain the happy life, the more eagerly a man strives to reach it, the farther he recedes from it if he has made a mistake in the road; for when it leads in the opposite direction, his very speed will increase the distance that separates him." (1932: 99) 
journey to Belgium, Petrarch found in the library of Liege a lost manuscript containing a speech by Cicero entitled Oratio pro Archia (62 BCE). His defence of Archias was an enlightening essay on the place of the poet in society. It remains a central work in the Western canon, as it is the first Latin text that highlights the personal and social importance of the study of the Humanities as a fundamental tool for the ethical education of human beings. Impressed by the awe-inspiring truth contained in the text, the Italian poet did not hesitate to copy it by hand. From that moment in time, Cicero's brief but fascinating text had a decisive impact on Petrarch's mind. The bonae litterae were conceptualized as being a powerful weapon for the ethical fashioning of humans, a means to cultivate a virtuous nature in men and women: learning, knowledge and wisdom made a human being a more benevolent, noble and sublime creature. ${ }^{8}$ Thus, the heart of Cicero's Pro Archia is a passionate laudatio humanitatis, that is to say an enthusiastic apology of humanistic culture, conceived of as being not just mere erudition, but as the genuine cultivation of humanity itself, as the integral (i.e., both intellectual and moral) education of human beings capable of the greatest feats in life, to the benefit of themselves and of others. The study of the bonae litterae is the most privileged of ways to cultivate the plenitude and self-realization of the homo humanus - a human being that is aware of the vulnerability of everything human and of the sublime nature of humankind. Hence, Humanism is the knowledge of our own limits; it is the acknowledgement of our shared vulnerability.

The ultimate aim of human knowledge is to be and to last on the planet -i.e., to guarantee humans' survival in some way. The historical moment when we happen to live is truly critical. The face of the world we live in has changed dramatically over the last decades of the 20th century and in the first decade of the 21 st century. In this complex world of ours, humans might feel overwhelmed by the sheer complexity of reality. No longer do we live in a world of certainty and encyclopedic knowledge; we live in a world of accelerating historical and technological change instead, and also at a time of an urgent need for producing new knowledge that might help us cope with a complex reality where events have an outstanding global dimension and planetary implications. Knowledge as a form of treasure passed on from one generation to another gives us a sense of safety, but habitual ways of understanding can prevent us from responding contemporaneously to now-problems and now-realities. Knowing the world nowadays is a confusing and thrilling experience at the same time: we humans are extensions of body and imagination into the past and into the future, and, what is more, we are on the precarious edge of critical change right now. But

8 Marcus Tullius Cicero's original Latin text reads as follows: §15 "Ego multos homines excellenti animo ac virtute fuisse et sine doctrina, naturae ipsius habitu prope divino, per se ipsos et moderatos et graves exstitisse fateor; etiam illud adiungo, saepius ad laudem atque virtutem naturam sine doctrina quam sine natura valuisse doctrinam. Atque idem ego hoc contendo, cum ad naturam eximiam et illustrem accesserit ratio quaedam conformatioque doctrinae, tum illud nescio quid praeclarum ac singulare solere exsistere." In his The Orations of Cicero. In Defence of Publius Sylla and Aulus Licinius Archias, C. D. Yonge translates this crucial passage literally: "I admit that many men have existed of admirable disposition and virtue, who, without learning, by the almost divine instinct of their own mere nature, have been, of their own accord, as it were, moderate and wise men. I even add this, that very often nature without learning has had more to do with leading men to credit and to virtue, than learning when not assisted by a good natural disposition. And I also contend, that when to an excellent and admirable natural disposition there is added a certain system and training of education, then from that combination arises an extraordinary perfection of character." (1927: 418) 
the good news is that the Humanities, and Literary Criticism as a significant part of them, appear to embody a wealth of power and promise to teach us the right path to take. Like science or philosophy, Literary Criticism can help us analyze and understand reality, the human condition and our place in the global mesh of things. In a world dominated by the mass media, in a world where access to an amazing mass of information worldwide is simply instantaneous, reading and critically interpreting literary works is of the essence. Being able to critically look at literary works as the most sublime embodiment of human languages is still an efficient and sensible way to cope with a complex world.

Practices of what could be called non-compliant Literary Criticism (outside of the sanctioned structures where knowledge has been traditionally produced or in liminal spaces where new forms of knowledge are being rehearsed) are truly promising; they expose us to intensities of critical thinking and aesthetic feeling that might completely overwhelm us. These are practices where Literary Criticism as the systematic and orderly meditation on the totality of the literary experience meet with other bodies of knowledge such as Philosophy, Social Sciences, Anthropology or even art forms other than literature. Like poetry or science, Philosophy in particular helps us to better understand reality and our place in the world. The power and promise of contemporary Philosophy are to be felt in the complex thinking of such philosophers as Alain Badiou, Jean-Luc Nancy, Maurice Blanchot, Giorgio Agamben and Gaston Bachelard, on aesthetics, art in general, literature in particular, religion, political philosophy and notions of community. In this sense, Philosophy has much food for thought to offer to Literary Criticism. The best Literary Criticism is possibly at the crossroads between poetry, philosophy and other art forms. In addition, people inside and outside academia addressing contemporary problems and issues (philosophical, artistic, political, sociological, linguistic, anthropological, scientific, religious, economic, gender-related issues, among others) are creating new ways of knowing in a global world. There are brilliant, beautiful minds in both academic and non-academic contexts, rehearsing new forms of producing relevant knowledge. In this wider context, knowledge is not something already made, but something in the making, a true work in progress. In this respect, Literary Criticism is a practice where a mind interprets words beautifully arranged on a page and unravels unusually intense densities of meaning embedded in texts, so as to enlighten other readers' confrontation with works of art that are worth preserving and worth knowing. Thus, genuine Literary Criticism might bring us to the limit of what we know, it might be the perfect place to address the epistemological, ethical and political problems of today. We are still in the process of assimilating the insights of other disciplines or bodies of knowledge into the practice of Literary Criticism. These informing bodies of knowledge are not giving us the simplest solution; they are giving us provocations instead. They bring us to the edge of understanding, moving us away from the comforts of what we know. That edge is precisely essentially interdisciplinary or transdisciplinary, and it is moving away from extreme specialization and into the right direction of a more holistic approach to knowledge and our experience of reality, of which literature is one more part. 


\section{BREATHING THROUGH THE FEET: LYRIC PHILOSOPHY AND LYRIC CRITICISM}

Brevity is possibly the genuine mark of genius. Some of the landmark texts of the history of Western culture have been brief. Back in time, in the very cradle of lyric poetry, Sappho of Mytilene is the perfect embodiment of conciseness and brevity. The tattered fragments of her poems that have survived the passage of time evoke the power of her language to reveal truths or uncover certain realms of experience with brevity of form and yet with astounding depth of meaning. Thomas Paine's Common Sense (1776), Ralph Waldo Emerson's ground-breaking essay "Nature" (1845), Karl Marx and Friedrich Engels' The Communist Manifesto (1848), Virginia Woolf's A Room of One's Own (1927) on the vindication of women's rights, or Stéphane Hessel's recent manifestos Indignez-vous! (2010) and Engagez-vous! (2011) are just luminous instances. The same applies to Literary Criticism: T. S. Eliot's "Tradition and the Individual Talent" (1919) remains a powerful landmark of the critical thinking of High Modernism. The point is that it takes just a handful of words to get relevant messages across to a sensitive readership if one knows how to choose le mot juste. In actual fact, brevity is indicative of a claritas of mind which is rare to find in the world where we happen to live nowadays - an age characterized by extreme verbosity and by a proliferation of critical writing (as opposed to primary or primordial writing) for which there is no precedent in History, as pointed out above. But the so-called Knowledge Society might well make us more ignorant than our ancestors were. Knowledge is constructed on the shoulders of giants, which is to say that it is built on the great achievements of the human beings that preceded us in time.

Canadian poet, philosopher, linguist, translator, cultural historian and typographer Robert Bringhurst knows what it means to make the most of the linguistic resources of English to efficiently convey relevant messages to humankind with utmost simplicity and profundity of thought. Some 600 years after the Renaissance, which represents a true peak of creativity in the progression of the imagination, Robert Bringhurst is the true embodiment of a humanist. He knows how to pursue creative writing, literary criticism and deep thinking with intellectual integrity, honesty and rigour. A consummate orator, Bringhurst is also the author of a prolific work that encompasses poetry, translation and essays on a whole array of topics. Among his main interests are not just poetry and language, but also the oral literatures of the First Nations of North America, the Pre-Socratics and Oriental philosophers, and typography, which he defines in the chapbook entitled The Typographic Mind as being "the sound of one hand speaking, vivid in the mind's eye, vivid in the mind's ear, and silent as a prayer." (2006: 4) Here we have chosen to focus on a brief text entitled The Library Opens Its Eyes, a work that Jorge Luis Borges, the author of "The Babel Library", might have loved reading if only he had had the chance to lay his hands and his eyes on it. This work is a folding limited-edition broadside containing a prose text of some 400 words which was commissioned by Simon Fraser University in celebration of its 40th anniversary and which was designed and set by Robert Bringhurst himself. There is a moving beauty about this prose text, which is held in the Rare Books and Special Collections at the Library of the University of British Columbia in Vancouver (Canada). To put it very simply, it is a one-page meditation on the relevance of books and libraries, literacy and literature, as part of the ongoing epistemological adventure of man on Earth. It 
is a tribute to a book culture, one that takes the side of genuine civilization, the side of the best that has been imagined and thought by humans over time. This is a relevant passage from The Library Opens Its Eyes:

Meaning trickles down the sides of nouns and verbs. This is how it happens that a sentence, like a hoofprint or a leaf, becomes a little watershed of meaning. Like water shaping earth, meaning nudges words and sentences around. It rolls them, sculpts them, polishes them, shapes them into landscapes we call stories. [...]

Library buildings are not often spherical, yet libraries - real ones, that is - with their square-cornered pages on squared-cornered shelves, are as round as the globe. Every book in the library leads to another, which leads to another, which leads to a book you have already read but cannot read again as you read it before, because of the others you've read in between. Invisible rivers and fogbanks and glaciers and blizzards of meaning sweep through the stacks. The library acts like a world, because it is a working model of the world, built from simple bricks of printed paper in an ever-changing order. Logical systems of organization never fit what it contains. Arbitrary systems - Melvil Dewey's decimals or the sequence of the alphabet, for instance - are the only ones that serve. Like the world and every creature in it - and like every stream and river- the library constantly changes its mind and follows its nose. You cannot step twice into the same collection of books.

Its lifeblood is meaning, but readers are its life. They are the neurons in its brain. Without them the library closes its eyes and shuts its mind - and yours as well - forever. (Bringhurst 2005: 1) ${ }^{9}$

This lyric and philosophical meditation illustrates the connection between brevity, truth, wisdom and beauty. Most importantly, this text is an example of what could be called Lyric Philosophy and Lyric Criticism: a species of critical writing and thinking that is at the crossroads between poetry, philosophy and pure criticism. The beauty and wisdom of The Library Opens Its Eyes testify to the unspeakable potential inherent in brevity. This jewel-like essay is a moving homage to language, to human knowledge and to human communication, but also a tribute to typography, which is the dance of the mind among words on the page. Everywhere being is dancing and Bringhurst's response to the endless exuberance and vitality of the world is precisely his poems, his essays and his translations. These are the gifts he gives us. His writing is born from his breathing through the feet. It is manifestly

9 Similarly, in What Is Reading For?, Bringhurst dwells on an ecological conception of reading: "In the widest sense, I think the term [reading] simply means paying attention to what's in front of you and trying to make sense of it. Fish do this as they swim through the water. Birds do it as they fly through the air or sit in the trees or on lamp posts waiting for breakfast. Earthworms do it as they poke through the sod, and I do it, not only in the library but also when I'm listening to those birds or looking at the water and thinking about those fish. This foundational kind of reading is much older than the oldest protoliterate inscriptions, older than human language, older than the first, nameless primates, climbing around in the trees of northern Africa some sixty million years ago." (2011: 17) And in another short prose meditation entitled "Reading What Is", Bringhurst further elaborates on this notion of preliterate reading: "Reading is different from looking or watching. It is listening with the eyes, evaluating signs against a lexicon of memories. We were reading waves and rivers, winds and clouds, the tracks of moose and grouse and hare, long before we started reading words. We were also reading stories with our ears a hundred thousand years before there were any writers writing. The reading we do now -novels, poems, the daily paper- owes its life to that apprenticeship in paying ecological attention.” (2006: 195) 
moving that he should accomplish such deep thinking with few words. The wisdom and beauty of brevity resides precisely in its capacity to unveil truths that are too obvious to be seen, because, as Saint-Exupéry put it long ago, l'essentiel est invisible pour les yeux.

Robert Bringhurst himself is a representative example of what it means to be an independent thinker, a brave translator, a self-made scholar writing at the margins of Empire, outside academia, and making statements of lasting value on the nature of poetry and the essence of knowledge. His beautifully written essays are exemplars of lyric and ecological criticism, or a form of Literary Criticism that does not strictly follow traditional academic conventions. One of the most astounding insights of Robert Bringhurst into the nature of poetry is this: he feels that poetry is an attribute of reality. Poetry is a quality of reality; words just happen to be the material out of which his poems and essays are made, but they partake of the music of being. ${ }^{10}$ Poetry is being, and being is pervasive, inescapable and eternal. At the heart of his poems is the primordial encounter between self and world, between the perceiving subject and the perceived reality. At the interface between bone, blood and breath, on the one hand, and mountains, birds and trees, on the other hand, are human speech and the mind. Like H. D. Thoreau, he might go to the woods to feel truly alive amid the manifold forms of life that the forest embodies. Humility, silence, peace and quiet, gratitude, the unstoppable stillness of being: this is what he finds there. To Bringhurst, poetry is a form of concentration and his poems and his essays are his way of getting involved in, not taking control of, the great feast of being, which is otherwise known as what there is to pay attention to. It seems that authors ${ }^{11}$ like Robert Bringhurst are part of the real power and promise of genuine Literary Criticism - one that truly cares about humanity and about beings, both human and nonhuman, and that is truly sensitive to the fragile harmony inherent in a world where biocentrism rather than anthropocentrism rules.

\section{THE HIDDEN HARMONY: A MANIFESTO FOR 21 ${ }^{\text {ST }}$ CENTURY LITERARY CRITI- CISM}

In the 1980s Italian novelist and critic Italo Calvino wrote a slim volume titled Six Memos for the Next Millennium, a most interesting meditation on the main characteristics the literature of the new millennium would have. It was a detailed anatomy and a comprehensive picture of the new landscapes of literature in the 21 st century. Needless to say, it

10 In his groundbreaking essay "Everywhere Being Is Dancing. Knowing Is Known”, Bringhurst dwells on the deep connection between poetry and knowing: "I don't know how poetry knows. What it knows I also cannot say, though I have heard poetry say it, so I know it in that passive sense. [...] I would rather say that poetry is one among the many forms of knowing, and maybe it is knowing in the purest form we know. I would rather say that knowing freed from the agenda of possession and control - knowing in the sense of stepping in tune with being, hearing and echoing the music and heartbeat of being - is what we mean by poetry." (2007: 15)

11 There are other relevant Canadian authors like Jan Zwicky, Don McKay, Tim Bowling, Dennis Lee or Tim Lilburn who cultivate lyric, philosophical and ecological criticism too. Their essays and pieces of Literary Criticism occupy a liminal space between poetry and philosophy, and their intellectual alertness to their world is essentially lyric and ecological. Their writing testifies to their respectful humility in the face of the world at large. Thus, poet, philosopher and musician Jan Zwicky has concentrated her efforts on elucidating the deep connections between poetry, philosophy and music in ambitious books like Lyric Philosophy (1992), Wisdom \& Metaphor (2004) and Plato as Artist (2009). 
was no random prediction or futurology, but a well-informed diagnosis of what the future of literature might bring to readers, and it was based on Calvino's own readings, insights into the nature of literary works of art and vast experience as a writer himself. ${ }^{12}$ As pointed out above, Literary Criticism could be defined as the dance of the intellect among poetical words, for poetry is the very centre of literature. One can sense Calvino's mind dancing among words in this stimulating essay indeed. When confronted with a literary text, critics try hard to unveil the hidden harmony and the densities of meaning embedded in a work of art, but also to grasp their universal worth and their irresistible appeal to innumerable potential readers. There is no end to literary interpretation, for there is no end to human curiosity or to the infinite layers of meaning embedded in a text. Literature is inexhaustible, and so is Literary Criticism. What follows is a brief manifesto for 21 st-century Literary Criticism, that is to say a list of the main principles this body of knowledge made out of words should ideally follow in the near future.

1. Paying attention to words. It may sound like a truism, but the first principle is paying attention to what is. When reading and analyzing a literary work of art, it is of the essence for critics to breathe through their hands and eyes, and to listen through their ears, in the light of what the work under scrutiny has to say of value to readers. This entails going beyond the limits of the well-wrought urn of the literary text in search of fruitful connections with other bodies of knowledge and areas of experience that may help the critic understand a specific work. What is more: the literary work of art is not an isolated specimen; it belongs among a constellation of individual works that make up the totality of literary tradition, which is polyglot and polyphonic and goes beyond temporal and spatial boundaries. ${ }^{13}$ The critic is

12 In this fascinating book-length essay, Italo Calvino situates within the perspective of the new millennium the "values, qualities, or peculiarities of literature" (1988: 1) that are very close to his heart: lightness, quickness, exactitude, visibility and multiplicity.

13 In High Modernism, tradition remains a central concept. Tradition is a treasure, not a burden, and it is to be found in the works of literary ancestors and, most importantly, in the green world through a form of concentrated attention: "To have gathered from the air a live tradition / or from a fine old eye the unconquered flame / This is not vanity" (1995: 542), sings Ezra Pound in Canto 81. Pound's extended meditation on the importance of tradition is scattered in the form of luminous fragments throughout The Literary Essays of Ezra Pound, edited by T. S. Eliot in 1954. As early as December 1913, in an essay entitled "The Tradition", the poet was preaching an essential lesson: "The tradition is a beauty which we preserve and not a set of fetters to bind us." (1954: 91) Somewhere else in the same essay, he claims: "A return to origins invigorates because it is a return to nature and reason. The man who returns to origins does so because he wishes to behave in the eternally sensible manner. That is to say, naturally, reasonably, intuitively." (1954: 92) Pound conceives of tradition as being a matter of collective effort sustained throughout time: the present builds on the achievements of the past, and there is no other way to produce great literature. This is the view of the craftsman, who is armed with the conviction that literature is no soloist's enterprise, but rather a matter of attention and accuracy on the part of the most talented human beings. Similarly, T. S. Eliot discusses the concept of tradition in "Tradition and the Individual Talent" (1919). Eliot's elemental lesson was that tradition is 'the juice of the past' and the lifeblood of poetry, and that tradition leaves nothing en route: "Tradition [...] cannot be inherited, and if you want it you must obtain it by great labour. It involves, in the first place, the historical sense [...] The historical sense compels a man to write not merely with his own generation in his bones, but with a feeling that the whole of literature of Europe from Homer and within it the whole of the literature of his own country has a simultaneous existence and composes a simultaneous order." (1975: 38) 
expected to pass judicious judgment on literary works, so he/she should have a deep knowledge of the totality of literature if his/her value-judgements are to be authoritative and trusted. Hence, going back to primary works, going back to the origins, is of paramount importance. Needless to say, secondary sources can shed light on the work under scrutiny and make literary study a scientific endeavour, but literary critics must always return to the original work of art and from there proceed to other relevant texts. This is methodological rigour.

2. Relevance and truth, also known as intellectual honesty and integrity. This fundamental principle could be expressed differently: Don't say that for which you don't have evidence. If "art, according to Plato, is a dream for awakened minds, a work of imagination withdrawn from ordinary life, dominated by the same forces that dominate the dream, and yet giving us a perspective and dimension on reality that we don't get from any other approach to reality" (Frye 1964: 102), then a literary critic ought to be respectful towards truth, have something relevant to say and say it with the utmost sincerity. The ultimate mission of Literary Criticism is to unveil the hidden pattern in literature: the totality of our literary experience. Truth, knowledge and wisdom are inextricably linked to each other in this context. Because of the primacy and superiority of the original literary work of art, the only thing left after we have said whatever it is we had to say about a literary work is silence.

3. Clarity, intelligibility and beauty: elegance of style. Simple, clear and understandable language, legibility and intelligibility are not incompatible with complexity of thought or difficult, deep thinking. Direct and simple language always has some force behind it. Literary Criticism should avoid abstractions and vague words which obstruct any simple or direct statement. As Robert Browning put it in the nineteenth century, less is more. Hence, beauty and economy of language are the true marks of great literary criticism. Thinking and singing may go hand in hand in a piece of literary criticism. To write literary criticism we must have something relevant to say, but that in turns means having a certain potential of verbal energy. Finding an elegant style in the practice of literary criticism is no easy task, and yet it is central to the whole endeavour of grasping the essence of literary works to the benefit of potential readers and scholars. Some of the unforgettable voices of twentieth-century criticism (Bloom, Kenner or Frye, among others) had an elegant style of their own that made them truly memorable and a pleasure to listen to.

4. Emotional, imaginative and rational approach to the study of literature. Literary Criticism happens in the domains of the human imagination and creativity, reason and universal emotions. ${ }^{14}$ It is also a verbal art made out of words by the human

14 Let us have a look at the etymology of two crucial words: 'emotion' and 'experience'. According to the $O x$ ford English Dictionary, an emotion is "a strong feeling deriving from one's circumstances, mood, or relationships with others", but also "an instinctive or intuitive feeling as distinguished from reasoning or knowledge". It comes from the mid-16th century French émotion, from émouvoir, 'excite', based on the Latin emovere, from $e$ - (variant of $e x$-) 'out' + movere 'move'. The current sense dates from the early 19th century. Now, if we have a look at the Indo-European root of the word experience (per-), we learn that it means attempt, test, risk, and that it points to an exterior, to the experiential, to innocence and experiment. Experience means putting the self in relation to the world and to others, just to see what happens when we test ourselves against the world. The meaning is simply transcendental at its very ancient and primordial linguistic root. But the Indo-European root 
mind. Frye's contention is that "Our imagination is what our whole social life is really based on. [...] In practically everything we do it's the combination of emotion and intellect we call imagination that goes to work." (1970: 135) Literary Criticism is no exception to this fundamental principle: it brings together emotion and intellect to shed light on literary works of art that have much of value to say about reality and about the human condition. Creativity is also at stake here: it means having original ideas that have value. Some of the preeminent minds of twentieth-century Literary Criticism embraced potent intuitions that led to even more powerful insights into the nature of literature. Like the minds of the authors they scrutinized, their minds were creative minds. It is our contention that the firm roots of 21st-century Literary Criticism are still imagination, reason and emotion.

5. A holistic approach to Literature as part of the totality of human knowledge. Being is one, and so is truth, and so is knowledge. It seems that the promise of Philosophy, Cultural Studies, Anthropology and Social Sciences should not be overlooked when it comes to literary studies. An interdisciplinary, transdisciplinary or multidisciplinary approach to Literary Criticism is part of the power and the promise of the 21 st century. The best Literary Criticism might be at the crossroads between poetry, philosophy and other art forms or bodies of knowledge informed by words. After all, all of them are constructs of the human imagination, and interdisciplinarity offers a most promising kaleidoscopic look at the object of study. Philosophy, History, Law or Religion are works of the human imagination, and the world revealed by these bodies of knowledge is the world of genuine and permanent human civilization. According to Frye, they represent

a more highly organized way of using words. We find knowledge and information in these studies, but they are also structures, things made out of words by a power in the human mind that constructs and builds. This power is the imagination, and these studies are its products. When we think of their content, they're bodies of knowledge; when we think of their form, they're myths, that is, imaginative verbal structures. (Frye 1964: 154-155)

Humanity is not a collection of unconnected monads. There are always the others. The self is not an isolated sphere, closed on the outside, floating aimlessly amid the vastness of reality. It is more like a tree, whose branches grow upwards in search of light, sunshine and oxygen, and whose roots grow downwards in search of nourishing minerals and water. This is just to say that the self is the self vis à vis the others and the world at large, and that knowledge remains a gigantic collective enterprise. The unstoppable sense of continuity of humanity resides precisely in the unbroken link that unites the living with the dead and the unborn. In this context, like other bodies of knowledge that are worth cultivating and expanding, Literary Criticism is a secular enterprise. It is as old as literature, and literature

also points to the idea of motion: to experience means to cross a space, to go outside, to achieve a goal. Through experience, inner and outer realities come into close contact with one another, the entire body and the mind are involved in the process, a transitional space holds interior and outside in a pleasurable tension. The transitional space we cross offers an amazing potential and opportunities for growing; and Literary Criticism takes place precisely at the point where experience (the experience of reading and absorbing a literary work) crosses into knowledge (a systematic and orderly understanding of what is going on in literature as a whole or totality). 
is as old as humanity. The promise and the power it embodies are as simple as this: it will keep on shedding light on fundamental areas of human experience that find expression in literary works of art. Art and science are inexhaustible instruments of mental production, and so is Literary Criticism. As far as we know, 21st-century Literary Criticism is hybrid, kaleidoscopic and transdisciplinary; it offers views on human nature that are nowhere else to be found.

\section{REFERENCES}

Badiou, A. 1999. Manifesto for Philosophy. New York: State University of New York Press.

BringhuRst, R. 2005. The Library Opens Its Eyes. Burnaby, British Columbia: Simon Fraser University.

2006. The Typographic Mind. Kentville, Nova Scotia: Gaspereau Press.

-2006. "Reading What Is". Reading Writers Reading: Canadian Authors'Reflections. Ed. D. Schaub. Edmonton: University of Alberta Press / Jerusalem: Hebrew University Magnes Press. 195.

2007. Everywhere Being Is Dancing. Twenty Pieces of Thinking. Kentville, Nova Scotia: Gaspereau Press.

- 2009. Selected Poems. Kentville, Nova Scotia: Gaspereau Press.

2011. What Is Reading For? Rochester, New York: Cary Graphic Arts Press.

Calvino, I. 1988 Six Memos for the Next Millennium. Cambridge, Massachusetts: Harvard University Press.

Cicero, M. T. 1927. The Orations of Cicero. In Defence of Publius Sylla and Aulus Licinius Archias. Trans. C. D. Yonge. London: G. Bell and Sons Ltd.

Eliot, T. S. 1975. Selected Prose by T. S. Eliot. Ed. F. Kermode. London: Faber and Faber.

FrYe, N. 1964. The Educated Imagination. Bloomington and Indianapolis: Indiana University Press.

1970. The Stubborn Structure. Essays on Criticism and Society. London and New York: Methuen.

HeIDEGGER, M. 1985. Unterwegs zur Sprache. Frankfurt am Main: Vittorio Klostermann. 1988. Identität und Differenz (Identidad y diferencia). Ed. bilingüe de Arturo Leyte y trad. de H. Cortés y A. Leyte. Madrid: Anthropos.

Humboldt, W. 1978. Werke in Fünf Bänden. Vol. III: Schriften zur Sprachphilosophie. Darmstadt: Wissenschaftliche Buchgesellschaft. 
Lear, J. 1988. Aristotle: The Desire to Understand. Cambridge: Cambridge University Press.

Ortega y gasset, J. 1964. Obras completas. Madrid: Revista de Occidente.

Pound, E. 1954. The Literary Essays of Ezra Pound. Edited with an introduction by T. S. Eliot. London: Faber and Faber.

1995. The Cantos of Ezra Pound. New York: New Directions.

SenecA, L. A. 1932. Moral Essays. Vol. II. Trans. J. W. Basore. The Loeb Classical Library. Harvard: Harvard University Press.

Zwicky, J. 1992. Lyric Philosophy. Toronto: University of Toronto Press. 2003. Wisdom \& Metaphor. Kentville, Nova Scotia: Gaspereau Press. 2009. Plato as Artist. Kentville, Nova Scotia.: Gaspereau Press. 
